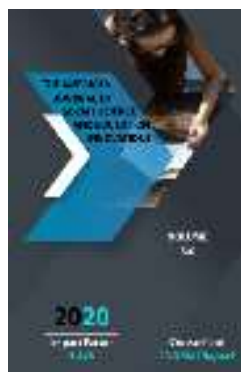

\title{
Using Debate Method In Teaching English Language To Tourism Students At Higher Education Institutions
}

\author{
Umarova Sarvinoz Sardorovna \\ Lecturer, Faculty Of Philology, Urgench State University Urgench, Uzbekistan
}

Journal Website:

http://usajournalshub.c

om/index,php/tajssei

Copyright: Original

content from this work

may be used under the

terms of the creative

commons attributes

4.0 licence.

\section{ABSTRACT}

The aim of the article is twofold: first, to discuss essential teaching method of «Debate» and to point out the importance of utilizing the following pedagogical methodology during English teaching classes. Article also attempts to reveal the efficiency of using this method while teaching tourism students to English vocabulary.

\section{KEYWORDS}

Debate, English, Karl Popper's method, tourism, skills, development of critical thinking.

\section{INTRODUCTION}

Recently, tourism has become one of essential industries of national economy. Its advantages over other sectors of the economy are that tourism provides equal opportunities for all countries to enhance their economic situation. Today, not only historical or traditional, but also new types and forms of tourism are emerging, and these new trends are leading the industry to be considered not only as a source of foreign exchange inflows, but also as one of the key factors in the regional development. As a result, this particular field of economy is taught in many universities and the number of those who want to study this field is growing day by day. 
In order to become a high-level specialist in this field, it is vital to understand the peculiarities of the economy of different countries, to know their traditions, culture, religion and etc. Tourism teaches people to communicate with people of different mentalities and gives new knowledge about people of many nationalities. A foreign language plays a significant role in the life of a representative of modern society, since its study is directly related to the development of the cultural level of person, improving him as a person.

The modern reality is such that students of non-linguistic areas demonstrate an ambiguous attitude towards the subject "Foreign language". A significant part of students indifferent towards learning a foreign language and this situation begins to form at school and is subsequently transferred to the process of learning it at the university, since this discipline is often not directly related to the life plans of students. Often, students have a negative attitude towards this subject as very difficult, practically impossible to master. Taking this into account, it is necessary to consider the issue of the formation of motivation for mastering a foreign language among students of non-linguistic areas of training in order to increase the efficiency of educational activities in this discipline and improve professional training in general.

\section{LITERATURE REVIEW}

Teachers strive to use their time more efficiently in class, but this is not enough. To solve this problem, it is important to motivate students for high-quality homework, as well as improve training programs to optimize the educational process. In fact, $80 \%$ of the successful organization of lessons depends on the correct design, organization and implementation of the educational process.

The right method will increase students' motivation and the quality of their learning. Using different methods, teachers should follow the principles of teaching a foreign language. One of the modern teaching methods is debate, which contributes to the development of many skills necessary for effective communication in any field.

The Merriam-Webster Dictionary offers the following definition of debate: "Debate is a competition of words and arguments; formal discussion of any topic in accordance with certain rules". Western scholars such as $M$.

Zaleski, B. Taylor define debate as a competition, a game in which two groups representing different views on a given problem express their reasoned point of view in order to convince opponents. This game is distinguished by a clear organization, the presence of appropriate rules and the orientation of the participants to reveal the objective truth. This truth is determined by collecting the votes of participants at the end of the debate, or by the decision of the judges observing the course of the discussion. [3] Particular attention is paid to the skills of argumentation, the level of speech development of the participants.

"Debate" as an educational technology forms all four types of skills in students: listening, reading, speaking and writing. At the stage of preparation for the games, speakers (players) analyze literature, prepare basic notes, annotations, abstracts, notes, collections of quotations, briefly write down the structure of speech, which develops reading and writing as communication skills. During the game of 
debate, listening and speaking skills are improved.

Debate, on the one hand, requires players to have certain skills, and on the other, it promotes the development of these skills, namely: critical thinking, research and organizational skills, as well as listening and writing skills.

As an educational technology, debate can address the following objectives:

- Developing: promote the development of intellectual, linguistic qualities, creative abilities.

- Educational: contribute to the formation of a culture of argument, tolerance, and recognition of the multiplicity of approaches to solving the problem;

- Communicative: learning activities are carried out in interpersonal communication, learning takes place in the process of joint activities.

This topic is relevant, because, despite the advantages of this method, debate is rarely used when teaching English. Debate methods allow participants to understand and formulate their opinions and contribute to the formation of respect for the opinions of opponents.

\section{METHODS AND RESULTS}

The author attempts to use comparative analysis in this work by analyzing various classification of debate teaching methodology. The first and main step in any debate is to formulate a topic and this is not considered as east task. A "good" theme should:

- provoke interest;

- Be balanced and give equal opportunity to teams in presenting quality arguments;
- Have a clear wording;

- Stimulate research work;

- Contain the possibility of discussion at various levels.

In teaching tourism students, the topics should be directly related to tourism field. For example: "Development of the tourism industry in Uzbekistan". The approval team presents their case, in which they provide arguments and evidence that tourism in our country is developing rapidly. The opponents prove that, on the contrary, due to the popularity of foreign resorts, there is an outflow of tourists from Uzbekistan. The discussion is conducted according to the rules and regulations. [1]

Depending on the goals and objectives, the debate in the classroom can take different forms. T.V. Svetenko in her book "A Guide to Debates" classifies debates as follows.

- "Classic Debates". This is a format where two teams of three are involved, and the rest of the students are passive listeners, either "reviewers" or judges. However, it is difficult to involve everyone in such a debate in one way or another, so this type has rather limited use in the classroom.

- "Express Debate". In them, the phase of orientation and preparation is kept to a minimum. Preparation is carried out directly in the lesson according to the textbook material. This type of use of the debate format can be viewed as an element of "feedback", reinforcement of educational material, or as a form of enhancing cognitive activity.

- "Modified debate". They use separate elements of the debate format, or debates, in which some changes in the rules are 
allowed .Making changes allows the whole group to be involved. [2]

For educational purposes in studying English for students of the "Tourism" specialty, the Karl Popper debate format is best suited. This type of debate is designed to develop work in teams so that students work together both in preparing for the debate and in the debate itself.

This format originated as a program that develops the skills of reasoning and critical thinking. It is the simplest and most optimal for beginner debaters.

Today, tourism professionals often have to not only communicate with foreign colleagues, but also be able to correctly express their thoughts in English when discussing serious issues, making management decisions and discussing them in a team.

Therefore, it is important for a modern specialist to master the vocabulary of the tourism business, be able to negotiate, work in a team, and be able to express their thoughts, hear and understand a foreign partner. All of these skills can be effectively practiced using Karl Popper's debate format.

Karl Popper's Debate Program allows to develop the following skills:

- Dialogical speech;

- Listening;

- Use of professional vocabulary in a given situation;

- Quick response to the opponent's statement;

- Public speaking and the ability to conduct a dialogue in English;

- Ability to form and defend their point of view in English.
- The purpose of this format:

- To master a special form of discussion;

- To expand theoretical knowledge of the English language;

- To consolidate grammar and vocabulary on the material that meets the needs of the "Tourism" field;

There are three types of Karl Popper debates performances:

1. Constructive speech:

In this type of speech, arguments are introduced and advanced by the speaker. The approver provides an initial view of the case, which will determine the structure of the entire round. Denying party conflicts with approving party and presents his case. All arguments must be presented in these two speeches.

\section{Denial speech:}

In such a speech, you need to refute the arguments and restore your system of arguments after "Attacks" of opponents. Here, a significant role is played by details, it is important to answer all the arguments of opponents and comment on how effective they confirm or deny the topic. In these speeches are not allowed new arguments. Participants must develop existing arguments through evidence and reasoning.

\section{Closing speech:}

This speech should draw attention to the main contradictions of positions, as if summing up the results of the debate. Speakers should summarize - how there was a debate about who was stronger and why. There should be no new arguments in this speech.

During the debate, team members have the opportunity to speak out, ask questions. The 
lexical concepts are introduced related to the state of hotels, roads, the level of personnel training, climatic features of resort areas and tourist facilities, etc. During the discussion, the teacher has the opportunity to assess the level of assimilation of the passed material by each of the participants in the debate.

\section{CONCLUSION}

In conclusion, it can be stated that debate is a modern and effective method in organizing foreign language teaching. The use of the "Debate" method in English lessons with students of the "Tourism" direction is effective, because it makes it possible to successfully apply the theoretical knowledge gained, consolidate listening, speaking, writing and reading skills, freely conduct dialogues and discussions within a given topic. Due to the variety of debate formats, they can be used at different stages of training and in any areas of student training. This pedagogical technology increases the motivation of students for independent study of a foreign language and encourages conscious actions in communicative situations.

\section{REFERENCES}

1. Karl Popper's debate Program // Dem club (Karl Popper's debate program // Dem club) Available at: http://www.debater. ru/ab2formats4.htm (accessed 10.09.2020).

2. Svetenko T.V. A Guide to Debate: A Study Guide for Educators and Students. [Electronic resource] URL: ru.idebate.org/ sites / live / files / Svetenko_book.pdf p.123 (date accessed 14.10.2020).

3. Zaleski M. Using Debate in Second Language Teaching // Idebate.
International Debate Education Association. 2004. V. 1. Issue 2. P. 32-41.

4. Pol'dyaeva O.V. Vozmozhnosti tekhnologii «Debaty» [Possibilities of the Technology «Debate»]. School technologies, 2007, no. 1, pp. 89-92. (in Russian)

5. Ispol'zovanie diskussii na zaniatiiakh inostrannogo iazyka $v$ ramkakh problemnogo obucheniia pri podgotovke sovremennykh spetsialistov [The usage of the discussion at the lessons of a foreign language in problem-solving approach to modern professional training]. Available at: https://www.hse.ru/pubs/share/direct/ document/74846569 (accessed 16 January 2018). 